(c) American Dairy Science Association, 2004.

\title{
L-Selectin and Chemotaxis Throughout Bone Marrow Granulocyte Maturation in the Bovine
}

\author{
E. Monfardini, ${ }^{1}$ V. Van Merris, ${ }^{1}$ M. Paape,${ }^{2}$ L. Duchateau, ${ }^{1}$ and C. Burvenich ${ }^{1}$ \\ ${ }^{1}$ Department of Physiology, Biochemistry, and Biometrics, \\ Faculty of Veterinary Medicine, University of Ghent, \\ Salisburylaan, 133, Merelbeke 9820, Belgium \\ ${ }^{2}$ Bovine Functional Genomics Laboratory, \\ USDA-ARS, Beltsville, MD 20705
}

\begin{abstract}
Polymorphonuclear neutrophilic leukocytes (PMNL) play a pivotal role during inflammation. Bone marrow (BM) reserves are depleted as cells are released into circulation for recruitment to infection sites. Expression of L-selectin on the cell membrane allows neutrophils to roll along the activated endothelium. Whereas mechanisms leading to recruitment to infection sites are well established, expression of BM adhesion molecules in cows is limited. In this study, we assessed Lselectin expression and chemotactic response to zymosan-activated serum (ZAS) in bovine BM cells and in circulating neutrophils. Isolated blood PMNL and BM cells were used from 9 dairy cows, for quantifying Lselectin expression using flow cytometry, and from 12 dairy cows for chemotaxis studies. All granulocytic maturation stages expressed L-selectin. The percentage of cells fluorescing increased significantly in BM band and mature granulocytes and reached maximal expression on circulating neutrophils. Bone marrow band and segmented cells showed the highest L-selectin density. Chemotaxis through micropore filters in response to zymosan-activated fetal bovine serum was first observed in the myelocytic and metamyelocytic stages, and it increased with maturation and release into the blood stream. From these results, we conclude that Lselectin expression varies among stages of granulocytic maturation within the BM and differs from circulating PMNL. Further, BM cells are capable of migration starting at the metamyelocytic stage, and compared with BM cells, circulating neutrophils are more chemotactively active.
\end{abstract}

(Key words: bone marrow cell, polymorphonuclear neutrophilic leukocyte, L-selectin, chemotaxis)

Received November 27, 2003.

Accepted June 1, 2004.

Corresponding author: C. Burvenich; e-mail: Christian.Burvenich @UGent.be.

\begin{abstract}
Abbreviation key: $\mathbf{B M}=$ bone marrow, $\% \mathbf{F}=$ percentage of cells fluorescing, MFI = mean fluorescence intensity, $\mathbf{S D F}=$ stromal-derived factor, ZAS = zymosanactivated serum.
\end{abstract}

\section{INTRODUCTION}

During infection, PMNL are the first cells recruited, attracted by chemotactic agents such as cytokines released from activated endothelium and macrophages. During this process, chemoattractants released from endothelial cells cause circulating PMNL to marginate and trigger the shedding of membrane-bound L-selectin. This allows for a firm CD18-mediated adhesion of the PMNL to the endothelium (Butcher, 1991).

Impaired PMNL chemotaxis has been shown to lead to a more severe disease status (Van Werven et al., 1997). During experimentally induced Escherichia coli mastitis in cows, the capability of PMNL to respond to chemotactic stimuli has been shown to relate negatively to the outcome of the disease (Kremer et al., 1993). Following acute infection, a decrease in L-selectin expression on peripheral blood PMNL was reported (Diez Fraile et al., 2003) and was accompanied by a concomitant leukopenia and shift in the circulating PMNL pool from mature to immature forms (Heyneman et al., 1990; Van Oostveldt et al., 2002). Approximately 48 h after an $E$. Coli IMI, circulating leukocyte counts start to approach normal values, and cell surface expression of L-selectin begins to recover. At that point, $50 \%$ of the blood PMNL are band cells (Monfardini et al., 1999), and myelocytes and metamyelocytes can be found in the blood stream (Diez Fraile et al., 2003). These results suggest that following the onset of an acute infection, the profound chemotactic stimulus induced by the bacterial endotoxin could cause bone marrow (BM) mobilization of band cells, myelocytes, and/or metamyelocytes. Similar to bovine, severe stress in humans is associated with trauma and infection, and activation of complement is required to release segmented granulocytes or band cells, but rarely metamyelocytes, from the BM into the circulation (Jagels and Hugli, 1992). 
Mechanisms leading to PMNL recruitment to inflammatory sites have been widely studied (Smits et al., 1998; Paape et al., 2002). Shedding of L-selectin is a compulsory step and is a limiting factor for PMNL recruitment to sites of infection. However, our knowledge about adhesion molecules on BM cells in the bovine is limited.

Important studies have been carried out in humans and mice on the mobilization of BM cells following the administration of the potent stem cell attractor stromal derived factor (SDF)-1 (Kim and Broxmeyer, 1998; Voermans et al., 2000; Wright et al., 2002). Less information is present concerning mechanisms underlying the mobilization of immature BM cells following inflammatory stimuli.

The vascular bed of the BM is a trilaminar wall. It comprises the luminal layer, which is an endothelium lining, and forms a selective barrier between the BM and blood. The medial layer consists of a basal membrane, which is irregular and often absent for long stretches. The outer surface is formed by adventitial cells with phagocytic properties (Mazo and von Andrian, 1999). The regulation of cell egress from the marrow can be related to 1 ) the porosity of this trilaminar barrier (Weiss, 1965), 2) the ability of granulocytes to negotiate these pores when they are smaller than the diameter of the cell (Lichtman, 1970), and 3) chemical and physiological modulators that could act on the porosity of the BM-blood barrier (Weiss, 1965) or on granulocytes directly (Aiuti et al., 1997; Klut et al., 1997; Frenette and Weiss, 2000).

In vitro collagen-coated membranes have been an effective tool to elucidate blood PMNL responses to chemotactic stimuli in the bovine (Smits et al., 1998) and have been used with human BM cells in response to a chemotactic gradient of SDF-1 (Kim and Broxmeyer, 1998). During the inflammatory process, bacteria are able to activate complement, resulting in the production of C5a (Shuster et al., 1997). In vitro studies demonstrate that C5a and zymosan-activated serum (ZAS) are potent chemoattractants for circulating PMNL, as well as BM cells (Nagahata et al., 1995; Klut et al., 1997; Smits et al., 1998).

A recent technique developed by Van Merris et al. (2001) allows for the isolation and fractionation of the $\mathrm{BM}$ cells into 3 fractions containing myeloblasts and promyelocytes, myelocytes and metamyelocytes, and band cells and segmented granulocytes. Flow cytometric analysis and light microscopy prove that the isolated cells belong to these populations of the PMNL lineage $\mathrm{BM}$ cells, and the technique has proven to be useful for performing functional studies on granulocytes (Van Merris et al., 2002).
The objective of this study was to use this BM cell isolation method for providing some insights on L-selectin expression and on the chemotactic response of BM myelocytes, metamyelocytes, band cells, and mature granulocytes in comparison with circulating PMNL.

\section{MATERIALS AND METHODS}

\section{Animals, Blood, and BM Sampling}

Nine healthy cows were selected for studying the expression of L-selectin, and 12 cows were used for in vitro chemotaxis studies in BM cells and on circulating PMNL. Blood samples (30 mL) were aseptically collected from the external jugular vein into Vacutainer tubes containing EDTA(BD Vacutainer Systems, Plymouth, UK). Bone marrow samples were collected aseptically by sternal aspiration (Van Merris et al., 2001) within 15 min after slaughter in the abattoir at Ghent University (Melle, Belgium). Samples were transferred on ice in sterile tubes containing Iscove's Modified Dulbecco's Medium with $584 \mathrm{mg} / \mathrm{L}$ of L-glutamine (Gibco BRL, Life Technologies Inc.) supplemented with $10 \%$ fetal bovine serum (Gibco BRL) and $100 \mathrm{U} / \mathrm{mL}$ of lithium heparin.

\section{Fractionation of BM Cells and Isolation of Blood PMNL}

Bone marrow was fractionated into 3 stages of maturation (early immature cells: myeloblasts and promyelocytes; late immature cells: myelocytes and metamyelocytes; and mature cells: band and segmented cells) as previously described (Van Merris et al., 2001). Briefly, the BM suspension was layered on top of a 3-layer discontinuous column gradient (densities: 1.030, 1.060, and $1.080 \mathrm{~g} / \mathrm{mL}$, respectively). Following centrifugation $\left(1000 \times g, 20 \mathrm{~min}, 4^{\circ} \mathrm{C}\right)$, the 3 cellular fractions were retrieved, washed with $\mathrm{PBS}$, and resuspended to the required concentrations.

Blood PMNL were isolated using gradient centrifugation as described by other researchers (Heyneman et al., 1990) with slight modification. Three milliliters of whole blood were gently layered on top of a 2-layer discontinuous Percoll gradient (densities: 1.091 and $1.071 \mathrm{~g} / \mathrm{mL})$. After centrifugation $(1000 \times \mathrm{g}, 20 \mathrm{~min}$, $4^{\circ} \mathrm{C}$ ), the pellet containing the PMNL was retrieved by removal of the gradient. Contaminating erythrocytes were removed by hypotonic lysis, and PMNL were washed $2 \times$ with PBS. Only samples containing $>95 \%$ PMNL with a cell viability of $95 \%$ were used, as determined by exclusion of Trypan blue. 


\section{L-Selectin Expression}

L-Selectin expression for the 3 maturation stages for BM cells and circulating PMNL was carried out through an indirect fluorescent labeling technique (Wang et al., 1997; Monfardini et al., 1999). Briefly, the 3 cellular $\mathrm{BM}$ fractions and the PMNL were adjusted to $10 \times 10^{6}$ cells $/ \mathrm{mL}$ in PBS. Each $100-\mu \mathrm{L}$ aliquot of the pellet was incubated for $30 \mathrm{~min}$ at $37^{\circ} \mathrm{C}$ with $50 \mu \mathrm{L}$ of RPMI medium (control) or with $50 \mu \mathrm{L}$ of antibovine L-selectin mAb 11G10 (Wang et al., 1997). After centrifugation $\left(200 \times g, 10 \mathrm{~min}, 4^{\circ} \mathrm{C}\right)$ and washing with PBS, a second incubation of the resuspended pellets in $100 \mu \mathrm{L}$ of RPMI was made with $50 \mu \mathrm{L}$ of fluorescein isothiocyanate-labeled goat anti-mouse IgG ( $\mathrm{F}_{\mathrm{ab}}$ fragments) (Sigma Chemical Co.) in the dark for $30 \mathrm{~min}$ at $4^{\circ} \mathrm{C}$. Cells were washed $2 \times$ with PBS, fixed in $0.5 \mathrm{~mL}$ of $1 \%$ paraformaldehyde in PBS, and kept in the dark at $4^{\circ} \mathrm{C}$ until analyzed by flow cytometry. Each analysis was performed in duplicate as described subsequently.

\section{Flow Cytometry and Fluorescence Microscopy}

Fluorescence was measured using a FACScan flow cytometer (Becton Dickinson Immunocytometry Systems, San Jose, CA). Excitation wavelength was 488 $\mathrm{nm}$, and emitted fluorescence was measured between 530 and $560 \mathrm{~nm}$. Granulocytic precursors in each maturation fraction and circulating PMNL were gated in a forward scatter (cell size) vs. side scatter (granularity) dot plot. Percentage of cells fluorescing $(\% \mathbf{F})$ and mean fluorescence intensity (MFI) of selectively gated cells were used to quantify L-selectin receptor expression. The $\% \mathrm{~F}$ and MFI were corrected by subtraction of background fluorescence obtained by cells incubated only with secondary antibody.

Fluorescence microscopy (Axiocam 2; Zeiss, Germany) was used as a qualitative control to confirm flow cytometric data. Following indirect L-selectin labeling, cell suspensions were incubated with DNA-specific staining 4', 6-diamidino-2-phenylindole (DAPI, Molecular Probes) for $30 \mathrm{~min}$ at $4^{\circ} \mathrm{C}$ for nuclear staining. Cells were washed $2 \times$ in PBS prior to cytocentrifugation (Shandon, UK).

\section{Preparation of Zymosan-Activated Fetal Bovine Serum}

The ZAS was prepared as described by Lamote et al. (2004). Briefly, a bovine serum pool with $15 \mathrm{mg} / \mathrm{mL}$ of zymosan (Sigma Chemical Co.) was incubated at $37^{\circ} \mathrm{C}$ for $60 \mathrm{~min}$. After $1 \mathrm{~h}$ at $37^{\circ} \mathrm{C}$, the mixture was incubated at $56^{\circ} \mathrm{C}$ for $30 \mathrm{~min}$. The mixture was cooled and then centrifuged at $4^{\circ} \mathrm{C}$ for $15 \mathrm{~min}$ at $2300 \mathrm{rpm}$. The supernatant was stored at $-80^{\circ} \mathrm{C}$. Prior to use, the ZAS was diluted 1:5 with Hanks balanced salt solution (without calcium and magnesium; Gibco BRL) and filtered through a $0.22-\mu \mathrm{m}$ filter.

\section{Measurement of Chemotaxis}

A micropore membrane was used to assess the chemotactic ability of BM cells and of blood PMNL. Micropore inserts (12-mm diameter, $3 \mu \mathrm{m}$-pore size; Millicel PCF; Millipore, Bedford, MA) were coated with collagen using a $0.1 \%$ solution of calfskin collagen type I (Sigma Chemical Co.). To perform the assay, cells were adjusted to $10 \times 10^{6} / \mathrm{mL}$ in PBS. For the treated and the control groups, $200 \mu \mathrm{L}$ of either the PMNL suspension or BM cells were added to the upper chambers. For the treated group, $400 \mu \mathrm{L}$ of ZAS were placed into the lower chambers, whereas for the control group, $400 \mu \mathrm{L}$ of Hanks balanced salt solution were used. Both assays were incubated for $90 \mathrm{~min}$ at $37^{\circ} \mathrm{C}$ in $95 \%$ air and $5 \%$ $\mathrm{CO}_{2}$. The migrated PMNL and BM cells were counted with a Burker chamber at a magnification of $10 \times 40$. Results are expressed as the percentage of cells that migrated through the membrane. Each assay was performed in duplicate.

\section{Statistical Analysis}

The different maturation stages were compared for L-selectin expression (\%F and MFI) by a mixed model with cows as a random effect, using SAS (SAS Inst. Inc., Cary, NC). The 4 stages were compared pairwise by Tukey's multiple comparisons method with an overall error rate of $5 \%$. The effect of the maturation stage and chemotaxis on the percentage of migrated cells was assessed in a mixed model with cows as a random effect and maturation stage, ZAS activation, and their interaction as fixed effects. Maturation stages and ZAS activation were pairwise compared by Tukey's multiple comparisons method with an overall error rate of $5 \%$.

\section{RESULTS}

\section{Myeloid Isolation}

Density gradient centrifugation of bovine BM suspension revealed 3 different fractions: early immature (Fraction I), late immature (Fraction II), and mature granulocytic cells (Fraction III). Fraction I contained mainly myeloblasts and promyelocytes, Fraction II consisted of myelocytes and metamyelocytes, and Fraction III contained mainly band and segmented cells (Figure 1). Although fractions were not entirely pure, they proved to be useful to study the development of some granulocyte functions. 

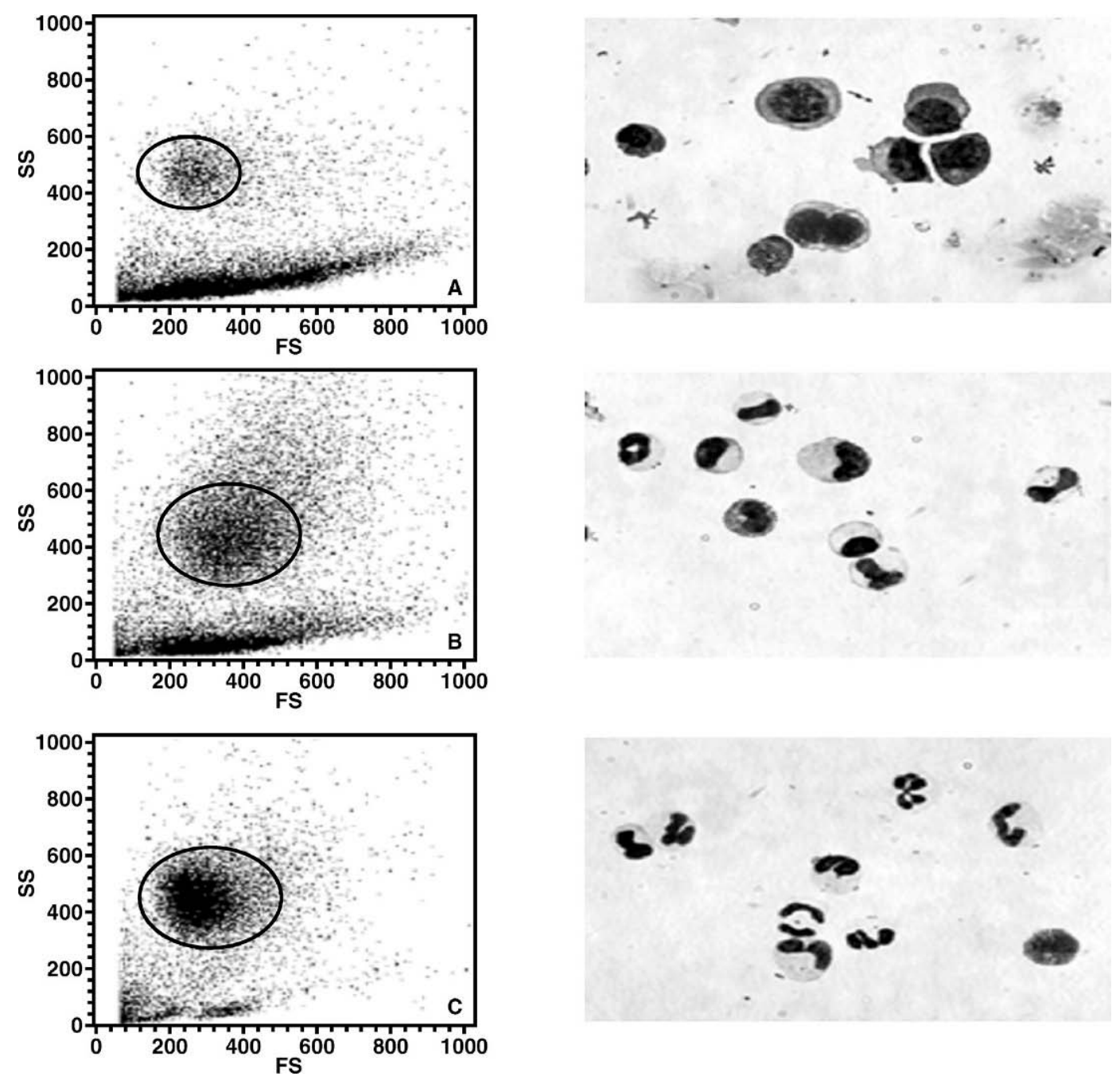

Figure 1. Flow cytometric analysis of the 3 fractions (Fraction I [A], Fraction II [B], and Fraction III [C]) obtained after density gradient centrifugation of bovine marrow cells: forward scatter (FS) vs. side scatter (SS) dot plot, and light microscopy of the gated cells obtained after sorting of the corresponding fractions (original magnification $\times 630$ ). Figure was published previously by Van Merris et al. (2001).

\section{L-Selectin Expression on BM Cells and on Blood PMNL}

For $\% \mathrm{~F}$, there were significant differences among the maturation stages $(P<0.0001)$. The $\% \mathrm{~F}$ increased from $1.98 \pm 0.61 \%$ in early immature cells (myeloblasts and promyelocytes) to $4.86 \pm 0.59 \%$ in late immature cells (myelocytes and metamyelocytes) $(P<0.01)$. For mature $\mathrm{BM}$ cells (band and segmented granulocytes), the $\% \mathrm{~F}$ was 10 -fold higher $(P<0.0001)$ compared with the late immature stage, but it was still significantly lower $(P$ $<0.0001)$ compared with blood PMNL $(74.09 \pm 0.59 \%)$. The MFI values averaged $20.36 \pm 0.54$ for the early immature cells, and they did not differ significantly $(P$ $>0.05)$ from the late immature cell fraction $(21.1 \pm$ $0.52 \%)$. A $20 \%$ increase $(P<0.0001)$ in MFI was observed in BM band and segmented cells $(25.33 \pm 0.52 \%)$.
Circulating PMNL exhibited significant lower MFI values $(20.75 \pm 0.52 \%)(P<0.0001)$ compared with mature $\mathrm{BM}$ cells (Figure 2, A and $\mathrm{B}$ ).

\section{Chemotaxis Assay Following ZAS on BM Cells and on Circulating PMNL}

The BM cells and circulating PMNL responded with migration through the collagen-coated inserts in response to ZAS. More than a 3 -fold increase $(P<0.001)$ in the response was shown for the (meta)myelocytic fraction $(25.47 \pm 3.9 \%)$ compared with myeloblasts and promyelocytes $(7.7 \pm 4 \%)$. The chemotactic response for band and segmented BM cells were similar $(P>0.05)$ to late immature cells. Circulating PMNL showed higher chemotactic values $(31.96 \pm 3.8 \%)$ than early immature BM cells $(P<0.0001)$. In the control group, both early 
a)

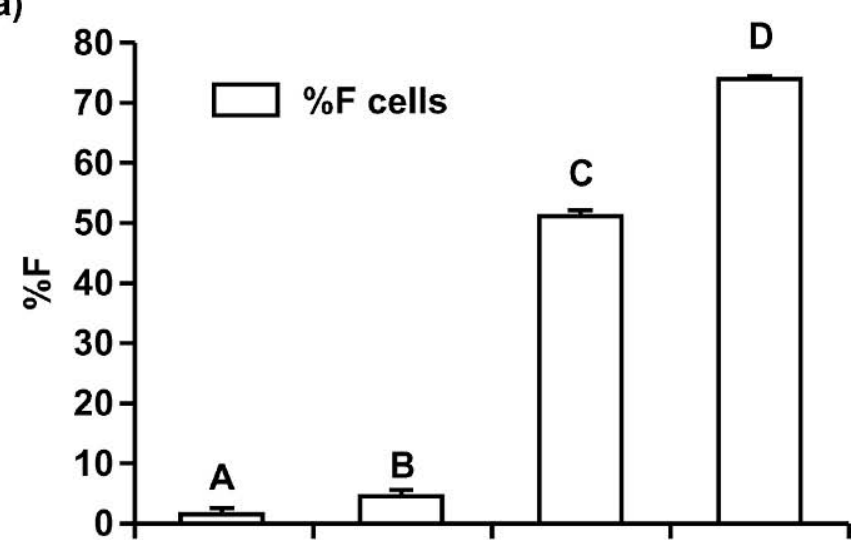

b)

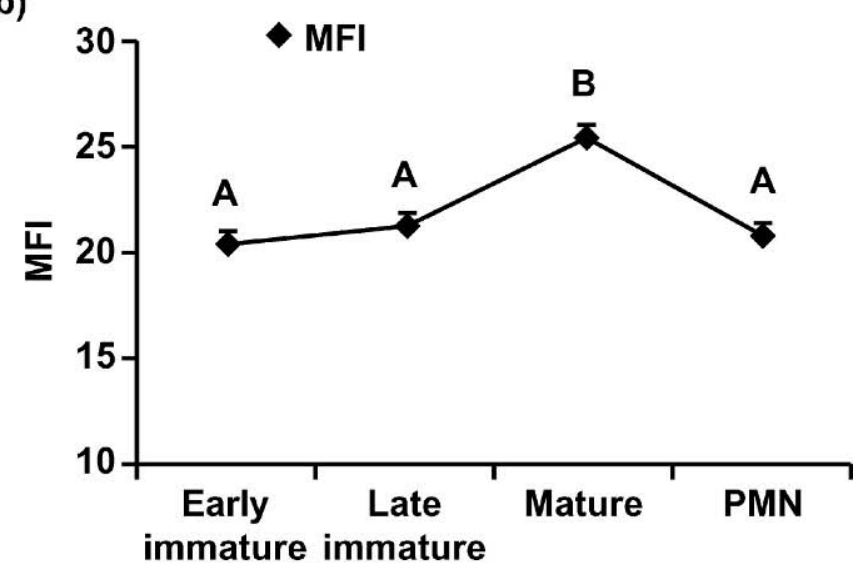

\section{Stage of maturation}

Figure 2. L-Selectin expression on cell surface of early immature, late immature, and mature bone marrow cells and on circulating PMNL. a) Percentage fluorescence $(\square: \% \mathrm{~F})$, b) mean fluorescence intensity (-; MFI). Data are expressed as means and $\mathrm{SE}(\mathrm{n}=9$ cows). Stages with different letters are significantly different $(P<0.05)$.

BM immature and mature cells and circulating PMNL showed similar low chemotactic values (maximum, 6.04 $\pm 3.8 \%)(P>0.05)$. Late immature cells had higher, but not significant $(P>0.05)$, chemotactic values $(14 \pm 4 \%)$ compared with the other cell populations. For this fraction, the analysis of the variability related to each individual animal revealed that in 3 of 12 cows, $>30 \%$ of the cells, on average, passed through the porous barrier, whereas only $5 \%$ of the cells migrated through for the remaining animals. No other cell fractions within the treated and control groups presented such a high discrepancy in values.

When treated and control groups were compared, stimulation with ZAS positively affected the chemotactic response of myelocytes and metamyelocytes with a significant difference $(P<0.05)$ in control $(14 \pm 4 \%)$ vs. treated $(25.47 \pm 3.9 \%)$ values. The ZAS also increased
Table 1. Percentage of migration of early immature, late immature, and mature bone marrow cells and circulating PMNL. Data are expressed as means $\pm \mathrm{SE}(\mathrm{n}=12$ cows). Treatments with different letters are significantly different from each other.

\begin{tabular}{lcr}
\hline & \multicolumn{2}{c}{ Chemotaxis \% } \\
\cline { 2 - 3 } $\begin{array}{l}\text { Stage } \\
\text { of maturation }\end{array}$ & $\begin{array}{l}\text { Zymosan } \\
\text { activated }\end{array}$ & \multicolumn{1}{c}{ Control } \\
\hline Early immature & $7.78 \pm 4.0^{\mathrm{a}}$ & $2.30 \pm 4.2^{\mathrm{a}}$ \\
Late immature & $25.47 \pm 3.9^{\mathrm{b}}$ & $14.00 \pm 4.0^{\mathrm{a}}$ \\
Mature & $23.02 \pm 3.8^{\mathrm{b}}$ & $3.39 \pm 3.9^{\mathrm{a}}$ \\
PMNL & $31.96 \pm 3.8^{\mathrm{b}}$ & $6.04 \pm 3.8^{\mathrm{a}}$ \\
\hline
\end{tabular}

$(P<0.0001)$ migration of band and segmented PMNL from $3.39 \pm 3.9$ to $23.02 \pm 3.8 \%$ and increased circulating PMNL from $6.04 \pm 3.8$ to $31.96 \pm 3.8$ (Table 1 ).

\section{DISCUSSION}

The PMNL originate in the BM through several granulopoietic steps, starting from the stem cell through several proliferation and maturation stages that include myeloblast, promyelocyte, myelocyte, metamyelocyte, band cell, and mature granulocyte. The mitotic or proliferative pool includes the first 3 stages, whereas metamyelocyte and band PMNL are considered as nonmitotic or the maturative pool (Moreira da Silva et al., 1994). Mature PMNL remain in the BM reserve pool until entrance into the circulation to replace PMNL recruited to extravascular sites. The presence of L-selectin on the cell surface of BM cells has been documented in humans and mice (Van Eeden et al., 1997; Frenette and Weiss, 2000). However, there is no information available on L-selectin expression on the different bovine BM granulocytic populations or on the comparison in expression of L-selectin between bovine BM cells and circulating PMNL. Our results show that in cows, Lselectin receptors are expressed during all stages of BM granulocyte maturation and on circulating PMNL. The percentage of cells expressing L-selectin significantly increased throughout the maturation stages from myeloblasts and promyelocytes to mature BM granulocytes. However, at this stage, L-selectin expression was still significantly lower when compared with circulating PMNL. The MFI reflects the number of L-selectin molecules expressed on the cell surface. It remained unchanged until the metamyelocytic stage and then peaked in BM band and segmented cells. Circulating PMNL exhibited significantly lower MFI values when compared with mature BM cells.

In our results, the trend in L-selectin expression in committed cells progressively increased throughout the granulocytes maturational pathway beginning at the myelocyte-metamyelocyte stage, with a strong up-regulation at the band and segmented PMNL stages. Data 
reported for human BM cells are in agreement with our findings. These cells also show an L-selectin downregulation during the proliferative phase and an increasing upregulation of L-selectin starting at the metamyelocyte stage, with mature BM granulocytes containing the highest expression of L-selectin (Lund-Johansen and Terstappen, 1993). Although some other receptors are found on BM cells capable of proliferation (complement receptor $\mathrm{C} 3 \mathrm{~b}$ and $\mathrm{C} 3 \mathrm{~d}$ ), it is not until these cells lose their proliferative capacity and enter the maturation phase that these receptors are found in appreciable numbers (Barrett et al., 1981). It is likely that, while the cell is dividing, there are too few metabolic pathways left for receptor synthesis.

Results from the present study show that when PMNL enter the circulation, the percentage of cells expressing L-selectin is significantly higher than in BM band and segmented granulocytes. However, the number of receptors on circulating PMNL (expressed as MFI) is significantly lower compared with BM band and segmented cells. L-Selectin expression on circulating human PMNL vs. BM cells in normal physiologic conditions corresponds to our findings. In experiments following cardiopulmonary bypass, a release occurs from the BM of a new PMNL population that expresses high levels of L-selectin compared with baseline levels for circulating PMNL (Van Eeden et al., 1995). Although the role of $\mathrm{L}$-selectin on $\mathrm{BM}$ cells is unclear, a recent study with human PMNL reported that L-selectin is shed as PMNL pass from the hematopoietic compartment into the circulating pool (Van Eeden et al., 1997).

Important insights on the role of L-selectin BM PMNL mobilization are provided in a study performed in mice. In that study, chimeric animals harboring progenitors from wild-type and L-selectin-deficient mice were administered fucoidan, a potent mobilizer of $\mathrm{BM}$ cells (Frenette and Weiss, 2000). Progenitors expressing Lselectin were preferentially mobilized from the BM into the circulation with a possible involvement of L-selectin in the release of PMNL from the BM.

The mechanisms that control the release of $\mathrm{BM}$ cells into the circulating pool in the bovine are poorly understood. Chemical and physiological modulators, such as SDF-1 and C5a, have shown a mobilizing effect on BM granulocytes of different species (Jagels and Hugli, 1992; Aiuti et al., 1997; Klut et al., 1997).

It is reasonable to think that the chemoattractants secreted by stromal cells in the BM microenvironment form various concentration gradients in the BM and that the BM microenvironment retains immature cells (Kim and Broxmeyer, 1998). When this equilibrium is broken (inflammatory process) or induced (physiological release) by effector molecules in the blood, the expression of L-selectin on BM granulocytes could be af- fected. In vitro experiments in humans reported that hematopoietic progenitor cells tend to be retained in the BM by SDF-1, even at low concentrations, and that these cells are released only following a higher concentration gradient of the same or of other similar chemotactic gradients, such as steel factor (Kim and Broxmeyer, 1998).

During acute mastitis, the BM cell population changes following migration of circulating PMNL to sites of infection: the pool of mature circulating PMNL becomes depleted, and cells from the maturative BM pool are mobilized into the circulation (Diez Fraile et al., 2003). At the same time, the BM proliferative pool increases in size to balance egress of band and mature granulocytes (Schalm and Lasmanis, 1976). Regulation of circulating PMNL levels is important in mounting a response to bacterial infections and in controlling and regulating other inflammatory states.

In bovine, no detailed information is available on migration activity of different BM cell populations or on the directed response to chemotactic inflammatory stimuli. In our study, a collagen-coated micropore membrane and ZAS were used to measure migration. Even though the results were variable, the chemotactic response of myelocytic and metamyelocytic stages to ZAS stimulation throughout the porous inserts was found significant. The cells with the greatest chemotactic activity were circulating PMNL. In several species, acute inflammatory stimuli, such as leukotriene $\mathrm{B}_{4}$ or $\mathrm{C} 5 \mathrm{a}$, stimulate the BM and accelerate the release of immature cells, but metamyelocytes rarely appear in the circulation. One requisite for the appearance of metamyelocytes in the circulation would be the expression of functional receptors on the recruitable cells. Receptors for C5a have been reported to appear at the metamyelocytic stage in rabbits (Jagels and Hugli, 1992). In vivo and in vitro experiments in humans demonstrated the presence of receptors for $\mathrm{C} 5 \mathrm{a}$ on all BM cell populations that contained granulocyte and monocyte precursors and the up-regulation of the CR3 (CD11b) receptor by C5a (Werfel et al., 1992). Recently, the presence of membrane CR3 receptors already at the promyelocytic stage and an intracellular pool of this receptor in the myelocytic stage were detected in bovine BM cells (Van Merris et al., 2002). This finding suggests that the cells at this stage can upregulate CR3 receptors following C5a stimulation. Some researchers have demonstrated that C5a is generated in large amounts following zymosan stimulation of bovine serum (Rainard et al., 1998). This finding allows us to speculate that, in our studies, the generated C5a bound to the CR3 receptors of metamyelocytes. However, even if these cells were shown to bind C5a, chemotactic response and locomotion might not be the direct and unique consequence of this event. 
Further studies would be needed to elucidate the exact implication of C5a and other molecules of the inflammatory response in the different bovine granulocytic fractions that induce migration and BM mobilization.

Following ZAS stimulation, rabbit circulating PMNL develop a polar shape, and cytoplasmic actin filaments assemble in the lamellipodium and uropod regions of the cell. In comparison, BM granulocytes show a reduced polarity and distribution of cytoplasmic actin redistribution (Klut et al., 1997). This supports our observation that bovine BM cells have a lower capacity to respond to chemotactic stimuli with active migration compared with circulating PMNL.

In our study, when BM cells were evaluated for random migration, myelocytes and metamyelocytes went through a transitional phase from proliferative (mitotic) to maturative (nonmitotic) pool and showed a strong, although not significant, random migration when compared with the mitotic and mature BM cells. An analysis of the variability related to each individual animal of this group revealed that 3 of 12 cows had very high values for random migration. More than $30 \%$ of the cells on average passed through the porous barrier, whereas only 5\% of the cells migrated through for the remaining animals. For all other treated (ZAS) and control (random migration) fractions, such variation within the same group was not observed. These findings lead us to postulate that during this transitional phase from the mitotic to the postmitotic pool, there is a cell behavior migration pattern, which is highly variable among animals, and that factors other than cell activation could promote cell migration. There are no reports in the literature on random migration of BM granulocytes from mitotic and postmitotic BM pools.

\section{CONCLUSION}

In conclusion, with these results, we demonstrate that in bovine BM, L-selectin receptors are expressed in all granulocyte maturation stages and that BM band and mature cells have the highest receptor density, even when compared with circulating PMNL. Our data also provide some insight on the capability of different bovine BM granulocytic maturation stages to react to chemotactic stimuli. We provided evidence that bovine $\mathrm{BM}$ cells started to migrate following ZAS activation at the myelocytic and metamyelocytic stage and that the response to this chemoattractant progressively increased to reach the highest point in mature BM granulocytes and circulating PMNL. However, little information exists in the literature about the mechanisms in bovine $\mathrm{BM}$ that result in migration in response to chemotactic inflammatory stimuli. Further investigations will be necessary to determine the role of L-selectin on
$\mathrm{BM}$ cell migration and the role of the different granulocytic stages in mobilization of PMNL during the inflammatory process.

\section{ACKNOWLEDGMENTS}

The authors thank Kristel Demeyere, Laboratory Manager, for her technical support and P. Rainard for his advice on ZAS preparation. V. Van Merris was supported by the Flemish Institute for the Encouragement of Research in the Industry (IWT-grant no. SB/993161).

\section{REFERENCES}

Aiuti, A., I. J. Webb, C. Bleul, T. Springer, and J. C. Gutierrez-Ramos. 1997. The chemokine SDF-1 is a chemoattractant for human CD34+ hematopoietic progenitor cells and provides a new mechanism to explain the mobilization of CD34+ progenitors to peripheral blood. J. Exp. Med. 185:111-120.

Barrett, S. G., K. S. Hansen, and D. F. Bainton. 1981. Differentiation of cell surface receptors on normal human BM myeloid precursors. Br. J. Haematol. 48:491-500.

Butcher, E. C. 1991. Leukocyte-endothelial cell recognition: three (or more) steps to specificity and diversity. Cell 67:1033-1036.

Diez Fraile, A., J. Mehrzad, E. Meyer, L. Duchateau, and C. Burvenich. 2004. Comparison of L-selectin and Mac-1 expression on blood and milk neutrophils during experimental Escherichia coli-induced mastitis in cows. Am. J. Vet. Res. 65:1031-1174.

Frenette, P. S., and L. Weiss. 2000. Sulfated glycans induce rapid hematopoietic progenitor cell mobilization: Evidence for selectindependent and independent mechanisms. Blood 96:2460-2468.

Heyneman, R., C. Burvenich, and R. Vercauteren. 1990. Interaction between the respiratory burst activity of neutrophil leukocytes and experimentally induced Escherichia coli mastitis in cows. J. Dairy Sci. 73:985-994.

Jagels, M. A., and T. E. Hugli. 1992. Neutrophil chemotactic factors promote leukocytosis. A common mechanism for cellular recruitment from bone marrow. J. Immunol. 148:1119-1128.

Kim, C. H., and H. E. Broxmeyer. 1998. In vitro behaviour of hematopoietic progenitor cells under the influence of chemoattractants: Stromal cell-derived factor-1, steel factor, and the bone marrow environment. Blood 91:100-110.

Klut, M. E., B. A. Whalen, and J. C. Hogg. 1997. Activation-associated changes in blood and bone marrow neutrophils. J. Leukoc. Biol. 62:186-194.

Kremer, W. D., E. N. Noordhuizen-Stassen, F. J. Grommers, A. J. Daemen, A. Brand, and C. Burvenich. 1993. Blood polymorphonuclear leukocyte chemotaxis during experimental Escherichia coli bovine mastitis. J. Dairy Sci. 76:2613-2618.

Lamote, I., E. Meyer, L. Duchateau, and C. Burvenich. Influence of $17-\beta$-estradiol, progesterone and dexamethasone on diapedesis and viability of bovine blood polymorphonuclear leukocytes. J. Dairy Sci. 87:3340-3349.

Lichtman, M. A. 1970. Cellular deformability during maturation of the myeloblast. Possible role in marrow egress. New England J. Med. 283:943-948.

Lund-Johansen, F., and L. W. Terstappen. 1993. Differential surface expression of cell adhesion molecules during granulocyte maturation. J. Leukoc. Biol. 54:47-55.

Mazo, I. B., and U. H. von Andrian. 1999. Adhesion and homing of blood-borne cells in bone marrow microvessels. J. Leukoc. Biol. 66:25-32.

Monfardini, E., C. Burvenich, A. M. Massart-Leen, E. Smits, and M. J. Paape. 1999. Effect of antibiotic induced bacterial clearance in the udder on L-selectin shedding of blood neutrophils in cows with Escherichia coli mastitis. Vet. Immunol. Immunopathol. 67:373-384. 
Moreira da Silva, F., A. M. Massart-Leen, and C. Burvenich. 1994. Development and maturation of neutrophils. Vet. Q. 16:220-225.

Nagahata, H., H. Nochi, K. Tamoto, K. Yamashita, H. Noda, and G. J. Kociba. 1995. Characterization of functions of neutrophils from bone marrow of cattle with leukocyte adhesion deficiency. Am. J. Vet. Res. 56:167-171.

Paape, M., J. Mehrzad, X. Zhao, J. Detilleux, and C. Burvenich. 2002. Defense of the bovine mammary gland by polymorphonuclear neutrophil leukocytes. J. Mammary Gland Biol. Neoplasia 7:109-121.

Rainard, P., P. Sarradin, M. J. Paape, and B. Poutrel. 1998. Quantification of $\mathrm{C} 5 \mathrm{a} / \mathrm{C} 5 \mathrm{adesArg}$ in bovine plasma, serum, and milk. Vet. Res. 29:73-88.

Schalm, O. W., and J. Lasmanis. 1976. Cytologic features of bone marrow in normal and mastitic cows. Am. J. Vet. Res. 37:359-363.

Shuster, D. E., M. E. Kehrli, P. Rainard, and M. Paape. 1997. Complement fragment C5a and inflammatory cytokines in neutrophil recruitment during intramammary infection with Escherichia coli. Infect. Immun. 65:3286-3292.

Smits, E., C. Burvenich, A. J. Guidry, and E. Roets. 1998. In vitro expression of adhesion receptors and diapedesis by polymorphonuclear neutrophils during experimentally induced Streptococcus uberis mastitis. Infect. Immun. 66:2529-2534.

Van Eeden, S., R. Miyagashima, L. Haley, and J. C. Hogg. 1995. LSelectin expression increases on peripheral blood polymorphonuclear leukocytes during active marrow release. Am. J. Resp. Crit. Care Med. 151:500-507.

Van Eeden, S. F., R. Miyagashima, L. Haley, and J. C. Hogg. 1997. A possible role for L-selectin in the release of polymorphonuclear leukocytes from bone marrow. Am. J. Physiol. 272:1717-1724.

Van Merris, V., E. Meyer, H. Dosogne, and C. Burvenich. 2001. Separation of bovine bone marrow into maturation-related myeloid cell fractions. Vet. Immunol. Immunopathol. 83:11-17.
Van Merris, V., E. Meyer, H. Dosogne, and C. Burvenich. 2002. Functional maturation during bovine granulopoiesis. J. Dairy Sci. 85:2859-2868.

Van Oostveldt, K., G. M. Tomita, M. J. Paape, A. V. Capuco, and C. Burvenich. 2002. Apoptosis of bovine neutrophils during masitis experimentally induced with Escherichia coli or endotoxin. Am. J. Vet. Res. 53:448-453.

Van Werven, T., E. N. Noordhuizen-Stassen, A. J. Daemen, Y. H. Schukken, A. Brand, and C. Burvenich. 1997. Preinfection in vitro chemotaxis, phagocytosis, oxidative burst, and expression of CD11/CD18 receptors and their predictive capacity on the outcome of mastitis induced in dairy cows with Escherichia coli. J. Dairy Sci. 80:67-74

Voermans, C., P. M. Rood, P. L. Hordijk, W. R. Gerritsen, and C. E. van der Schoot. 2000. Adhesion molecules involved in transendothelial migration of human hematopoietic progenitor cells. Stem Cells 18:435-443.

Wang, Y., M. J. Paape, L. Leino, A. V. Capuco, and H. Narva. 1997. Functional and phenotypic characterization of monoclonal antibodies to bovine L-selectin. Am. J. Vet. Res. 58:1392-1401.

Weiss, L. 1965. The structure of bone marrow. Functional interrelationships of vascular and hematopoietic compartments in experimental hemolytic anemia: An electron microscopic study. J. Morphol. 117:467-537.

Werfel, T., M. Oppermann, M. Schulze, G. Krieger, M. Weber, and O. Gotze. 1992. Binding of fluorescein-labeled anaphylatoxin C5a to human peripheral blood, spleen, and bone marrow leukocytes. Blood 79:152-160.

Wright, D. E., E. P. Bowman, A. J. Wagers, E. C. Butcher, and I. L. Weissman. 2002. Hematopoietic stem cells are uniquely selective in their migratory response to chemokines. J. Exp. Med. 195:1145-1154. 